\section{Recovery from Paraquat Poisoning}

Brit. med. F., 1968, 3, 292

Paraquat (a dipyridilium compound) is a herbicide that is inactivated on contact with the soil. Cases of accidental human poisoning (Bullivant, 1966; Swan, 1967; Campbell, 1968) have been reported in which the herbicide proved highly toxic when ingested before inactivation. In such cases a minimal amount may prove fatal (as recorded by Bullivant), and mere contact of the poison with the oral mucosa may cause severe and widespread pathological changes.

Necropsy findings in cases of human poisoning show that the following changes may occur: intrapulmonary and subpleural haemorrhages and, on microscopy, proliferation of the epithelium of the terminal bronchioles and of the alveolar cells themselves, central zone necrosis of the liver, acute tubular necrosis of the kidneys, myocarditis, and congestion and haemorrhage of the mucosa of the stomach and oesophagus.

A further case is here described in which recovery occurred after involvement of the kidneys and myozardium and probable hepatic involvement and gastrointestinal tract ulceration.

\section{CASE Report}

An 11-year-old boy was admitted to the Dunedin Public Hospital on the night of 8 January 1968. He gave a five-hour history of sore throat and abdominal pains that had come on shortly after taking a mouthful of fluid from a soft-drink bottle. Because of its taste this was immediately ejected. On discovering that it had cointained a solution of the weed-killer paraquat the parents took the boy to the casualty department of Dunedin Hospital, where gastric lavage was performed. He was subsequently admitted for observation.

He appeared fit and well and no abnormalities were reported on examination. However, two days after admission the tongue was found to be denuded, with a small ulceration on its tip. The urine on this day was found to contain a trace of protein and the blood urea level was $48 \mathrm{mg} . / 100 \mathrm{ml}$.

Three days after admission he began to vomit. The vomitus was noted to be blood-stained on occasion. He was unable to take further oral fluids and intravenous hydration was begun.

Four days after admission the blood urea level had risen to 141 $\mathrm{mg} . / 100 \mathrm{ml}$. The uric acid level was $10.5 \mathrm{mg} . / 100 \mathrm{ml}$., plasma creatinine $1.2 \mathrm{mg} . / 100 \mathrm{ml}$., bilirubin $1.4 \mathrm{mg} . / 100 \mathrm{ml}$., lactate dehydrogenase 240 units, hydroxybutyric dehydrogenase 150 units, and the alkaline phosphatase 123 Bessey Lowry international units. The chest $x$-ray picture was clear and the electrocardiograph showed $\mathrm{T}$-wave inversion in leads II, III, and $\mathrm{aVF}$ and a sinus tachycardia. The urine had a specific gravity of $1020, \mathrm{pH} 5.5$, and contained +1 protein and +1 sugar. On microscopy an occasional red blood cell and very occasional white blood cell per high-power field was seen. Casts were present in considerable numbers, mostly hyaline, but some contained cells and others were granular. The patient was started on hydrocortisone.

The blood urea reached a peak of $146 \mathrm{mg} . / 100 \mathrm{ml}$. five days after admission. The 24-hour urinary output at this stage was $1,350 \mathrm{ml}$. (at no stage in fact had the urinary output been less than $700 \mathrm{ml}$./ 24 hours). Subsequently t':e blood urea level fell slowly and had returned to normal levels 12 days after admission. By this time the urine was free of protein, but still contained some red blood cells and numerous hyaline and epithelial cell casts.

The serum alkaline phosphatase level had fallen to 83 Bessey Lowry international units after seven days, probably the upper range of normal for his age. The serum bilirubin was normal at this stage, but the serum transaminase level was 50 units. On comparison with the tracing two days after admission, the electrocardiograph five days later showed extensive $T$-wave inversion in the standard and limb leads and across the precordium. Eventually these changes receded, and one month later there was $\mathrm{T}$-wave inversion in leads III and V1 only.

At no stage was any abnormality found in the chest, and the chest $x$-ray picture remained clear at all times.

Renal function tests, performed two months later, showed a creatinine clearance of $120 \mathrm{ml} . / \mathrm{min}$., serum creatinine $0.8 \mathrm{mg} . /$ $100 \mathrm{ml}$., maximum specific gravity after pitressin 1025 , ammonium production $30 \mu \mathrm{Eq} / \mathrm{min}$. and total acidity $59 \mu \mathrm{Eq} / \mathrm{min}$.

\section{COMMENT}

In other reported cases of paraquat poisoning death has occurred after rejection of a mouthful of solution alone. At first (apart from the local corrosive action of the poison) patients may seem well for several days after ingestion, but, subsequently, radiological evidence of lung involvement or evidence of hepatic, renal, and cardiac involvement is seen to progress remorselessly over several days. The unusual lesions in the lungs have been shown in animal experiments to betray little evidence of their presence, but, in the absence of further dosing, to progress to death (Clark et al., 1966). It is noteworthy that in other cases described, as in this, the urea level has been seen to climb steadily, despite a good urinary output. In very few instances has recovery from paraquat poisoning been reported in humans.

Paraquat is described as a broad-spectrum contact herbicide which becomes inactivated on contact with soil. It is in widespread use throughout the world, and, because very small or no residues have been recorded in edible crops, chronic toxicity is said not to be a hazard in man. Ingestion before inactivation can be lethal, but the magnitude of the lethal dose to man is not known. From this and other reported cases, however, it would appear that very small amounts can cause widespread pathological changes that often lead to death.

I would like to thank Associate Professor E. G. McQueen, Director of the Poisons Information Centre, Dunedin Public Hospital, for encouragement and advice in the publication of this case.

W. I. MCKE.AN, M.B., CH.B.,

Medical Registrar. Dunedin Public Hospital, Otago, New Zealand.

\section{REFERENCES}

Bullivant, C. M. (1966). Brit. med. f., 1, 1272.

Campbell, S. (1968). Lancet, 1, 144.

Clark. D. G., McElligott, T. F., and Hurst, E. W. (1966). Brit. F. industr. Med., 23, 126.

Swan, A. A. B. (1967). Brit. med. F., 4, 551. 